\title{
SOFT POWER CONTEXT OF CHINESE INVESTMENTS TO THE EUROPEAN UNION: CHALLENGES VS. OPPORTUNITIES
}

\author{
Daniela Cvetanovska \\ Faculty of Social Sciences, University of Ljubljana, Slovenia \\ ORCID iD: https://orcid.org/0000-0003-4961-8277 \\ daniela.cvetanovska@student.uni-lj.si
}

\begin{abstract}
This paper presents a constructivist take on soft power, by analyzing the contextual factors which influence Chinese investments (COFDI) to the EU as a relevant soft power resource. The contextual analysis shows which constraining and stimulating (internal and external) factors condition COFDI in leveraging soft power for China. Additionally, the article provides solutions for soft power optimization, since soft power resources aim to entice and foster cooperative relations toward a 'win-win' behavior. The issues presented here have profound implications for future studies on soft power and the political economy of Chinese investments in the EU.
\end{abstract}

Keywords: Chinese Investments; EU; Soft Power; Context Analysis; Constructivism

\section{INTRODUCTION}

The nature of Chinese investments (hereinafter COFDI') in its possibility to leverage benefits for China, influence foreign environments, tap into technology and provide innovation opportunities, represents a prime tool of economic and political importance to China's rise. COFDI, as part of China's economy, possesses the capacity to leverage soft power or to undermine it, since fears or confidence in it are inseparable parts of perceptions on China. Even though COFDI soft power is able to thrive in many guises, its social identity implies that a multidimensional context and conditions shape its ability to leverage power. External and internal, political and economic factors exercise power over COFDI's actorness

${ }^{1}$ COFDI is usually referred in the literature as a technical term for Chinese outward FDI (foreign direct investment). 
as soft power resource. COFDI operational character, its firm specific and industrial profile, relation to both home country political style and interaction with host country market conditions, will primarily affect the possibility for leveraging soft power. Additionally, the compatibility of home country profile and the host country character can produce cultural, political and economic implications for both. These conditions are further buttressed by the historical relations of both countries as well as their position in the global power structures.

Given Chinese background of economic primacy, relations with the EU were considered strategic in a sense that EU possessed goods and advanced technology that would provide China sustainability in its further development. The governmental innovation policy related to China's central planning plays a relevant role in Chinese innovation development (Van Someren \& Van Someren-Wang, 2014). The "shadow of the Chinese state" (Brown 2008) in overtaking European economies is mainly evoked in WE (Western Europe) countries, where Germany presents one of the most attractive destinations of market and technology-seeking acquisitions (Hanemann and Huotari, 2016). This way the phenomena of COFDI gave rise to many debates regarding Chinese expansion to the 'Western world'. The EU is also known for its advantages of its open single market, the benefit of a single currency and unrestrictive monetary policy, integration in supply chains, investor friendly policies, and credit access to businesses. COFDI to the EU is especially interesting soft power case, since it has the opportunity to leverage advanced know-how, brands, provide market share and provide political leverage over a globally relevant region. In addition, EU-China economic integration has more potential and opportunities than US-China since this relationship has a globally determining character in shifting global policy, therefore more responsibility is required to be adequately managed.

As a consequence, European countries are divided whether COFDI is a friend or a foe. In such an environment, the influencing structure and context has implications on the soft power prosperity of COFDI to the EU. In order to assess the same, this article is structured as follows. The next section informs how and why COFDI to the EU ought to be analyzed as potential soft power resource. It highlights COFDI economic and political importance to its home country and how it can contribute to its growth. The third section deals with the context under which COFDI to the EU thrives by analyzing the challenging and beneficial aspects for leveraging soft power. It is within this setting the purpose of this article - namely to explain the main influencing circumstances on COFDI and propose directions under which soft power optimization can occur toward a 'win-win' cooperative solution. Therefore, the aptness of a constructivist approach is fitting to capture COFDI social character and the context in which it thrives. 


\section{SOFT POWER AND CHINESE INVESTMENTS TO THE EU}

Soft power is associated with resources invested in attraction and strategies behind using these resources to accomplish actors' interests (Chitty et al. 2016). It is often used to epitomize the capability of a state to influence other countries to do what it wants them to i.e. co-optation through attraction in setting moral example and fondness (Nye 1990; 2004; 2011). Some conceptualized power as an end itself, while others as a means to an end (Berenskoetter and Williams 2007). This concept is also referred in the CCP (Chinese Communist Party) broader nation building program (Edney 2012). Chinese investments have already been discussed as part of China's soft power package, referring mainly to the BRI project (Arif 2017; Clarke 2017; Zhou \& Esteban, 2018) and Chinese investments in Africa (Bodomo 2009; Fijałkowski 2011; Jaroslaw \& Kaluzynska 2013). At first Nye (soft power concept creator) excluded investments as soft power tool, but later Kurlantzick $(2007,1)$ suggested that investments are part of the business toolset (along with trade and foreign aid) for attraction of the Chinese economic model. He added that in the current Asian context, soft power "implies all elements outside of the security realm". The EU has on many turns recognized the importance of COFDI in its relations with China (See European parliament, 2018), especially since the onset of 2008 Global Financial Crisis (also the Great Recession) when a mini COFDI tsunami ${ }^{2}$ happened. Additionally, Eastern European countries are keener on Chinese capital influx, but receive less in comparison to the Western part. The majority of studies, dedicated to COFDI in developed countries, emphasize the asset upgrading, asset augmenting or in other words strategic asset seeking perspective of these companies. The 'spillovers' which happen through the internationalization of Chinese MNEs present a connecting juncture for overcoming economic gaps and stimulating integrated economies. This is in line with China's neo-techno nationalism³. For the most part, many COFDI invest in $R \& D$ centers in Europe in order to include Chinese firms in innovation ecosystems. With the aim of providing opportunities and facilitating the internationalization process, Chinese enterprises' overseas aspire to become more diversified and to advance from low valueadded activities through strategic industrial upgrading and innovation to higher value added products. Those are the reasons why Western European countries are more interesting for COFDI than the Eastern EU market. In the same vein, market-seeking is as much as relevant as asset-seeking determinant (Deng 2013). In both senses, Chinese MNEs play the role of transactional actors, supporting development and leveraging advantages through OFDI, whether it is know-how and technology or profit increase. The political significance is translated in COFDI grand projects such as the BRI ${ }^{4}$ (Belt and Road Initiative). This project is in line with China's sustainable development policy of increasing economic integration between

\footnotetext{
${ }^{2}$ COFDI to the EU made a fifty fold increase in the period of 8 years (2008-2016) (Hanemann and Huotari 2018).

${ }^{3}$ China's strategy is said to be characterized by neo-techno nationalism, where technological development pursued through globalization opportunities supports national, economic and security interests of China. See: Shim and Shin (2016).

${ }^{4}$ EU countries which joined the BRI are Greece, Portugal, Italy, Austria, Luxembourg, Hungary, Poland and Bulgaria.
} 
the countries along its corridors, covering primarily Asia and Europe. It is expected that Chinese exporters will hugely benefit from this initiative and the 'costs of foreignness' with European countries would be reduced while at the same time economic trade and cooperation with the neighboring states and the far-off states in Europe would be increased. Many argue that although the purpose of these projects is better integration of China within the global economy, establishing a parallel system of economic governance where China is the main player is an underlying objective. The establishment of NDB (New Development Bank), a WB (World Bank) alternative, and the establishment of AllB (Asian Infrastructure Investment Bank), an IMF alternative as the main body that funds the BRI, has given further momentum of Chinese international role in financial aid and investment. Through this project China is matching US leadership role by establishing itself as a regional and global power, where COFDI plays a germane part.

\section{A CONTEXTUAL ANALYSIS OF COFDI SOFT POWER POSSIBILITIES}

Constructivism assumes that meaning is "socially constructed" based on the meaning given to the material reality (Wendt 1992). Hence constructivists argue that actions, interactions, identity, beliefs, norms, interests and context, all have the influence to shape the international environment. Since the possibility to leverage soft power is also heavily influenced by the same factors, a constructivist approach through contextual analysis will detect the implicating conditions which encourage or challenge soft power capacity of COFDI to the EU. The thing about soft power is that it has inherently a 'win-win' (cooperative) character, which is a prerequisite for its successfulness. Therefore, adding the solutions component, which is later described in detail, assists in optimizing and improving the strategy and potential for soft power effectiveness.

Challenges

The abrupt change in economic interaction with the EU (COFDI burgeoning ${ }^{5}$ ), which at the same time supported China's continuous growth (He, et al. 2019), triggered the alarm and led to the $\mathrm{CAl}^{6}$ (Comprehensive Agreement on Investment) initiation. This was however, one among the many obstacles (Table 1) for COFDI soft power. Furthermore, acquisition of high-tech companies (especially German), activated the zero-sum lenses calling them asset stripping investments of European brands and reputation (Richet 2014). This was also coupled with the overstated US trade deficit with China (also zero-sum view since according to Stiglitz (2017), the US has overall profited of trade surpluses with many other countries) in the context of US-China high technology rivalry (which includes 5G, Artificial Intelligence,

\footnotetext{
${ }^{5}$ See: supra note 2.

${ }^{6}$ The first investment agreement negotiated on EU level (ever since 2013, and up to 2020 still not concluded) considered a paving contract for future investment agreements.
} 
semiconductors, the Internet of Things and quantum computing) where the EU was propelled to take the middle ground (European Think-tank Network on China 2020). The established Western structures show reluctance to COFDI (implicitly seen as part of China) due to the natural fears of power transition. As a result, de-globalizing and protectionist trends ${ }^{7}$ started occurring. Consequently, EU FDI screening mechanism for third countries ${ }^{8}$ (inspired by the US counterparts $^{9}$ ) was introduced and a change in tone happened, addressing China as EU's "systemic rival", instead of the previous "strategic partner" (Berkofsky 2019).

Another soft power challenge are the state-controlled COFDI involved in the crucial state sectors such as transportation, energetics, financial services, health, real estate and insurance. This is also related to the EU implicit perceptions of COFDI as Pax Sinica instrument, which is further buttressed by large cultural distance and different business practices - also in line with the yellow peril fears ${ }^{10}$. Fears of political leverage that China could use investments as a diplomatic instrument in order to get politically favorable outcomes (European Parliament 2018) negatively impacts COFDI perceptions. This especially refers to cases when EU level decisions in relation to China (or if it concerns China as a stakeholder) need to be made, some member states might oppose them. This was already the case when Greece, Hungary, and Croatia (as members of the BRI) opposed any strong language in the EU statement which supposed to support the ruling of the tribunal at the Permanent Court of Arbitration on the disputes in the South China Sea"1.

\footnotetext{
${ }^{7}$ Protectionist trade-restrictive measures between WTO members have increased seven-fold in the past years (2016-2018) which started with the bilateral tariffs on trade between the US and China; for more seeWTO (2018). Such is Trump's deglobalist "trade war" based on protectionist policies toward China which assumes that trade is a zero-sum game. This is pure anti-globalization stance toward open markets and unhindered capital flows which according to this view has served China and damaged the US.

${ }^{8}$ The EU investment screening regulation, initiated by the governments of Germany, France and Italy, was adopted and enforced it as of 10.04.2019. See European Commission (2020).

${ }^{9}$ See more the official U.S. Department of Treasury website on the Committee on Foreign Investment in the United States (CFIUS), https://home.treasury.gov/policy-issues/international/the-committee-on-foreign-investment-in-the-united-statescfius (25 March 2020).

${ }^{10}$ The Yellow Peril is a metaphor for East Asians as an existential danger and threat to the Western world. See Svetličic (2020).

${ }^{11}$ On July 12, 2016, the Permanent Court of Arbitration in The Hague released the ruling of the arbitral tribunal constituted under the UN Convention on the Law of the Sea (UNCLOS) on the case initiated by the Philippines in 2013 regarding China's claims and activities in the South China Sea. The arbitral tribunal ruled overwhelmingly in favour of the Philippines, determining that major elements of China's claim were unlawful. China reacted negatively to the ruling, maintaining it was 'null and void'. For more see the ruling of the Permanent Court of Arbitration(2016).
} 
Table 1: Exogenous and endogenous parameters which challenge and undermine COFDI soft power (Source: Author's own compilation)

\begin{tabular}{|c|c|}
\hline Exogenous (between and within countries) & Endogenous (firm-level to country) \\
\hline Western protectionism & Ballooning FDI and trade surplus \\
\hline Undermining neoliberal democratic values & $\begin{array}{l}\text { Chinese state-owned companies for control of } \\
\text { crucial industrial sectors }\end{array}$ \\
\hline The "information warfare" between US and China & $\begin{array}{c}\text { Lack of transparency and reciprocity in market } \\
\text { access }\end{array}$ \\
\hline Cultural xenophobia and yellow peril fears & $\begin{array}{c}\text { Fear of political leverage and revealing EU } \\
\text { deficiencies }\end{array}$ \\
\hline & Pax Sinica tool \\
\hline
\end{tabular}

Not less significant are the accusations of lack of transparency of Chinese official data (European Parliament 2018), saying that they are rather a reflection of the government's political targets than of the real economic situation. Transparency, alongside human rights and the established authoritarian communist party all undermine and are incompatible with the Western neoliberal democratic values, which are closely tied to soft power as a US based concept. As a result, an 'information warfare' is also taking place to destroy the image of China ${ }^{12}$ i.e. its soft power, where media are the instrument for imposing these narratives and the pandemic is being politicized to serve as a power debate.

Opportunities

The most obvious benefit some EU countries would get is the advantage of easy capital to sectors in need - which was the case in the aftermath of the Global Recession where COFDI was welcomed to alleviate the struggle. Another 2008 scenario of shifting the need for capital is also very likely in the post-pandemic period. Opportunities for COFDI soft power promotion (Table 2) are not only constrained to the financial side. Firm-specific advantages (FSA) of Chinese companies are already known in sectors such as telecommunications, artificial intelligence and renewable energy, even though COFDI is considered to mainly benefit China in innovation-related FSA through internationalization (He et al. 2019). Even though China is considered to benefits from EU's experience, know-how, competitiveness, pragmatic approach for integration and cohesion, the EU needs to realize that China is already a global technological powerhouse, thus their cooperation will provide mutual benefits.

\footnotetext{
${ }^{12}$ For illustration see Collinson (2020) and Korybko (2020).
} 
Table 2: Exogenous and endogenous opportunities which benefit and promote COFDI soft power (Source: Author's own compilation)

\begin{tabular}{|c|c|}
\hline Exogenous (between and within countries) & Endogenous (firm-level to country) \\
\hline China's development model and decline of US & Post-pandemic need for capital \\
\hline Brexit (EU pressure decreased) & Easy capital (low-cost financing) \\
\hline BRI and 17+1 cooperation & $\begin{array}{c}\text { Chinese leadership in Al, renewables and } \\
\text { telecommunications }\end{array}$ \\
\hline COVID19 China foreign aid & Spillovers to the European companies \\
\hline EU-China multilateral cooperation & $\begin{array}{c}\text { Glocalization of supply chains during COVID19 } \\
\text { pandemics }\end{array}$ \\
\hline Peaceful rise policy & Soft-balancing measure with China \\
\hline
\end{tabular}

Additionally, US leadership decline even before the pandemic leaves the door open to China who has the advantage over this position through the attractiveness of its development model. Moreover, the COVID19 pandemic has provided major setbacks (generating disruptive effects in the global economy affecting global trade routes and global value chains which are most of them tied back to China) where regionally localizing global value chains (glocalization) already takes place. The BRI and $17+1^{13}$ established initiatives are as well an immediate opportunity for COFDI. Even though these projects trigger mixed feelings among EU member states (especially Germany and France are skeptical considering these projects erode EU's authority in Central and Eastern Europe) and the US (as a Chinese power demonstration), China's peaceful rise policy ${ }^{14}$ coupled with multilateral approach ${ }^{15}$ (which should include Western countries as equal founding partners) and a unified and common narrative toward EU member states for both of these and future projects, can improve EU's response thereby avoiding a 'lose-lose' final outcome (Gabusi 2019; Di Donato 2020). These projects are great avenue for further cooperation which spillovers to other domains, providing a partnership platform. Even when hegemonic aspirations are perceived, this kind of cooperation is encouraged as a soft-balancing measure against China. This strategy, realized through a combination of economic interests, security concerns and domestic motives for counterbalancing, is used to maintain policies for preserving security and avoiding conflict with the hegemon (Casarini 2009, 11-12).

\footnotetext{
${ }^{13}$ The project was established in 2012 in the aftermath of the global financial crisis as sub-regional Chinese diplomacy to assist South-East European countries and develop large-scale infrastructure projects through Chinese investments. It comprises $12 \mathrm{EU}$ members and 5 Balkan countries. This project along with the BRI are constantly accused of undermining EU's cohesion and strengthening Chinese influence in this region through the foreign policy duality of China with the EU and concomitantly with its individual member states.

${ }^{14}$ This was an official policy under the leadership of Hu Jintao, which suggested that China's rise will not be a threat to peace and security, thereby avoiding confrontation during its emergence as a political, economic and military power.

${ }^{15}$ The EU and China are cooperating successfully in some multilateral formats, such as the United Nations Framework Convention on Climate Change (UNFCCC) regarding the uniform reporting rules to implement the Paris Agreement.
} 
Optimization of COFDI soft power can happen under specific set of buffering strategies which redefine the unfavorable conditions (Table 3). Since favorable perceptions are important for soft power (Nye 2011), aspects with implicit zero-sum game assumptions, hegemonic and imperialistic aspirations are therefore damaging.

Table 3: Exogenous and endogenous strategies for optimizing COFDI soft power (Source: Author's own compilation)

\begin{tabular}{|c|c|}
\hline Exogenous (between and within countries) & Endogenous (firm-level to country) \\
\hline Quid pro quo strategy & COFDI diversification \\
\hline Confucian humility in foreign policy & Philanthropic stewardship \\
\hline Reassert open door, peaceful rise and multilateralism & Learning and cooperation engagements \\
\hline COVID-19 public good provisions & COFDI and foreign aid without strings \\
attached/leverage
\end{tabular}

To counter this, China needs to show that COFDI is in line with this peaceful rise policy, open door reciprocity, and a contribution to the European economy. Therefore, sacrifices need to be made, since an assertive approach provokes antagonism, triggering fear and defensiveness. Keeping the practiced Confucian humility, wisdom and softness in its foreign affairs avoids overly deterministic perceptions as power demonstration. Emphasizing multilateral approach in leveraging initiatives, initiation of learning, exchange and mutual cooperation will avoid perceptions of aggressiveness. Moreover, the EU should also accept that some assumptions about China maybe wrong. The Chinese people apparently trust their political institutions, which was exemplified on how the country dealt with the pandemics outbreak (Li 2020). The civil society in China is not the something apart from or opposite the state. The Western normative view is not a universal measure of a (nation) state, since China is a civilization state with many systems and the state is the trusted head of the family as the guardian of the Chinese civilization (Jacques 2012, 183). A philanthropic and sociotropic stewardship approach is therefore necessary, since the US rose in power only through providing global public goods. Realizing the soft power benefits COFDI might provide China should be a paramount practice, meaning more Greenfield investment and joint ventures, and less acquisitions in the high tech sector i.e. COFDI diversification in order to subside fears and zero-sum perceptions. The EU needs to realize the benefits of increased economic integration and competition with China as well as to overcome cultural differences through learning and cooperation engagements. Central to this relationship will be a quid pro quo strategy in leveraging political outcomes, meaning no conditioning and lobbying in individual EU member states should be practiced. Both should watch and try not to overstep the boundaries of a cooperative behavior and the EU avoids using the CAI as a tool to straitjacket investment relations with China. 


\section{CONCLUSION}

COFDI soft power potential lies in the possibilities to improve perceptions toward China, economic integration and asset-seeking, as well as political leverage in the host countries where its capacity is always contextually constrained. Nonetheless, COFDI is internally constrained by the negative perceptions of state-interventionism, lack of transparency and reciprocity, political leverage, affecting greater division among EU member states and liability of foreignness. The external constraints lie in China's lack of neoliberal democratic values, the ongoing trade war with the US and increased protectionism, as well as the information warfare the COVID19 pandemics which encourages global sinophobia.

Giving solutions to the negative influences of the internal and external contexts, involves reconciling the differences and managing the possible damages if the negative events take a swing. Greater responsibility and sociotropic engagement is required by both. China needs to realize that assertiveness creates antagonism and defensiveness, which leads toward increased protectionism. On the other side, the EU needs to realize that its unique voice should be more responsively used, by avoiding bandwagoning to the US policy and contributing to the yellow peril fears. A win-win solution is necessary as a soft power prerequisite. This includes re-examining EU's assumption on China's state-permeated market economy with one-party state authoritarian rule. Instead the EU should learn and accept the differences between the Chinese understanding of a nation state and the Western one. 


\section{REFERENCES}

1. Arif, Beston Husen . 2017. "The Role of Soft Power in China's Foreign Policy in the 21st Century." International Journal of Social Sciences \& Educational Studies 3 (3): 94-101.

2. Berenskoetter, Felix, and Michael J. Williams, .2007. Power in world politics. Routledge.

3. Berkofsky, Axel. 2019. "China and the EU: "Strategic Partners" No More." Institute for Security and Development Policy. December. Accessed March 5, 2020. https://isdp.eu/publication/china-and-the-eu-strategic-partners-no-more/.

4. Bodomo, Adams. 2009. "Africa-China Relations: Symmetry, Soft Power and South Africa." China Review 169-178.

5. Brown, Kerry. 2008. "Chinese overseas direct investment-What kind of opportunity?" Royal Institute of International Affairs, January.

6. Casarini, Nicola. 2009. Remaking global order: the evolution of Europe-China relations and its implications for East Asia and the United States. Oxford: Oxford University Press on Demand.

7. Chitty, Naren, Li Ji, Gary D. Rawnsley, and Craig Hayden, . 2016. The Routledge handbook of soft power. Taylor \& Francis.

8. Clarke, Michael. 2017. "The Belt and Road Initiative: China's new grand strategy?" Asia Policy 24 (1): 71-79.

9. Collinson, Stephen. 2020. What's happening between the US and China is no cold war. 8 May. Accessed May 11, 2020.

https://edition.cnn.com/2020/05/08/world/meanwhile-in-america-may-8intl/index.html.

10. Deng, Ping. 2013. "Chinese Outward Direct Investment Research: Theoretical Integration and Recommendations. 通过研究中国对外投资发展理论: 现实与建议." Management and Organization Review 9 (3): 513-539.

11. Di Donato, Giulia. 2020. China's Approach to the Belt and Road Initiative and Europe's Response. Italian institute for international political studies. Accessed May 12, 2020. https://www.ispionline.it/en/pubblicazione/chinas-approach-belt-and-road-initiativeand-europes-response-25980.

12. Edney, Kingsley. 2012. "Soft power and the Chinese propaganda system." Journal of Contemporary China 21 (78): 899-914.

13. European Commission. 2020. Guidance to the Member States concerning foreign direct investment and free movement of capital from third countries, and the protection of Europe's strategic assets, ahead of the application of Regulation (EU) 2019/452. Communication from the Commission, Brussels: European Commission. Accessed May 1, 2020.

https://trade.ec.europa.eu/doclib/docs/2020/march/tradoc_158676.pdf. 
14. European Parliament. 2018. European Parliament resolution of 12/9/2018 on the state of EU-China relations. Texts adopted, Brussels: European Parliament. Accessed June 26, 2019. https://www.europarl.europa.eu/doceo/document/TA-8-2018-0343_EN.pdf.

15. European Think-tank Network on China. 2020. "Europe in the Face of US-China rivalry." Policy-oriented study, European Think-tank Network on China (ETNC), 190. Accessed May 1, 2020.

https://www.ifri.org/sites/default/files/atoms/files/etnc_report_us-chinaeurope_january_2020_complete.pdf.

16. Fijałkowski, Łukasz. 2011. "China's 'soft power'in Africa?" Journal of Contemporary African Studies 29 (2): 223-232.

17. Gabusi, Giuseppe. 2019. "No Losers? The BRI Factor in the China-EU Relationship." China: An International Journal 17 (4): 96-108.

18. Hanemann, Thilo, and Mikko Huotari. 2016. "A New Record Year for Chinese Outbound Investment in Europe." Mercator Institute for China Studies and the Rhodium Group, February.

19. Hanemann, Thilo, and Mikko Huotari. 2018. Chinese FDI in Europe in 2017: Rapid recovery after initial slowdown. Rhodium Group (RHG) and Mercator Institute for China Studies (MERICS).

20. He, Shaowei, Zaheer Khan, Yong Kyu Lew, and Grahame Fallon. 2019. "Technological innovation as a source of Chinese multinationals' firm-specific advantages and internationalization." International Journal of Emerging Markets 14 (1): 115-133.

21. Jacoby, Wade. 2014. "Different cases, different faces: Chinese investment in Central and Eastern Europe." Asia Europe Journal 12 (1-2): 199-214.

22. Jacques, Martin. 2012. When China rules the world: The rise of the middle kingdom and the end of the western world [Greatly updated and expanded]. Penguin UK.

23. Jaroslaw, Jura, and Kaja Kaluzynska. 2013. "Not Confucius, nor Kung Fu: Economy and business as Chinese soft power in Africa." African East-Asian Affairs 1.

24. Korybko, Andrew. 2020. U.S. info warfare about China's COVID-19 response is hypocritical. 26 April. Accessed May 3, 2020. https://news.cgtn.com/news/2020-0426/U-S-info-warfare-about-China-s-COVID-19-response-is-hypocriticalPZ68jDrmPm/index.html.

25. Kurlantzick, Joshua. 2007. Charm offensive: How China's soft power is transforming the world. Yale University Press.

26. Li, Eric. 2020. "Xi Jinping Is a 'Good Emperor'." Foreign Policy. 14 May. Accessed May 15, 2020. https://foreignpolicy.com/2020/05/14/xi-jinping-good-emperorcoronavirus/.

27. Nye, Joseph S. 1990. "Soft Power." Foreign Policy 80: 153-71. doi:10.2307/1148580.

28. - 2004. Soft power: The means to success in world politics. PublicAffairs.

29. - 2011. The future of power. Public Affairs. 
30. Permanent Court of Arbitration. 2016. "The South China Sea arbitration (The Republic of the Philippines v. the People's Republic of China)." Hague, 12 July. Accessed November 22, 2020. https://docs.pca-cpa.org/2016/07/PH-CN-20160712-PressRelease-No-11-English.pdf.

31. Popescu, Liliana, and Andreea Brînză. 2018. "Romania-China Relations. Political and Economic Challenges in the BRI Era." Romanian Journal of European Affairs 2 (18): 20 38.

32. Ravenhill, John. 2008. "Bridging the subfield boundaries." In The Oxford handbook of international relations., ., edited by Christian Reus-Smit and Duncan Snidal, 537-557. New York: Oxford University Press.

33. Richet, Xavier. 2014. "The internationalisation of Chinese firms: Growth, Motivations and Strategies." In Strategies of multinational corporations and social regulations: European and Asian Perspectives, edited by Xavier Richet, Violaine Delteil and Patrick Dieuaide. Springer Science \& Business Media.

34. Shim, Yongwoon, and Dong-Hee Shin. 2016. "Neo-techno nationalism: The case of China's handset industry." Telecommunications Policy 40 (2-3): 197-209.

35. Stiglitz, Joseph E. 2017. Globalization and its discontents revisited: Anti-Globalization in the Era of Trump. W. W. Norton \& Company.

36. Svetličič, Marjan. 2020. "From red scare to yellow peril: reality and fears on the rise of China in a historical context." Teorija in Praksa 57 (1): 163-183.

37. Van Someren, Taco C.R., and Shuhua Van Someren-Wang. 2014. Innovative China. Springer.

38. Wendt, Alexander. 1992. "Anarchy is what states make of it: the social construction of power politics." International organization 46 (2): 391-425.

39. WTO. 2018. Overview of developments in the International Trading Environment. Annual report by Director-General, WTO. Accessed November 20, 2019. https://www.wto-ilibrary.org/trade-monitoring/overview-of-developments-in-theinternational-trading-environment-annual-report-by-the-director-general2018_2273d63c-en.

40. Zhou, Weifeng, and Mario Esteban. 2018. "Beyond balancing: China's approach towards the belt and road initiative." Journal of Contemporary China 27 (112): 487-501. 